\title{
EFEKTIFITAS RELAKSASI NAFAS DALAM TERHADAP INTENSITAS NYERI DISMENORE PRIMER PADA REMAJA PUTRI
}

\author{
Santi, Winda Windiyani, Noorhayati Novayanti, Melsa Sagita Imaniar \\ D3 Kebidanan Universitas Muhammadiyah Tasikmalaya
}

(Santisusanti051999@gmail.com)

\begin{abstract}
ABSTRAK
Dismenore merupakan suatu gejala rasa sakit atau rasa tidak enak diperut bagian bawah pada masa menstruasi sampai dapat mengganggu aktivitas sehari-hari yang paling sering ditemui pada wanita muda dan reproduktif. Penyebab disminore primer ini disebabkan oleh prostaglandin, zat kimia yang memicu kram prostaglandin dalam jumlah sedikit dapat menyebabkan kram ringan. Gejala ini bisa berlangsung selama satu atau dua hari. Relaksasi nafas dalam bermanfaat untuk merelaksasi tubuh dan mengurangi rasa nyeri disminore. Penelitian ini bertujuan untuk mengetahui efektivitas relaksasi nafas dalam terhadap nyeri dismenore pada remaja. Metode pencarian artikel jurnal dilakukan secara elektronik dengan menggunakan beberapa database, yaitu: Google Garba Rujukan Digital (Garuda), dan Google Cendekia (Scholar Google), sehingga didapatkan 5 artikel untuk di review. Hasil studi literatur mengungkapkan bahwa efektivitas relaksasi nafas dalam sebagai upaya preventif yang dapat menurunkan skala nyeri dismenore dengan rata-rata hasil penelitian $\mathrm{P}$-value $=0,000$ yang berarti $\alpha<0.05$. Simpulan efektifitas relaksasi nafas dalam dapat menurunkan intensitas nyeri dismenore primer pada remaja putri.
\end{abstract}

Kata kunci : Nyeri haid, dismenore, relaksasi nafas dalam

\section{ABSTRACT}

Dysmenorrhea is a symptom of pain or discomfort in the lower abdomen during menstruation so it can interfere with daily activities which is most often found in young and reproductive women. The cause of primary dysmenorrhea is caused by prostaglandins, chemicals that trigger prostaglandin cramps in small amounts which can cause mild cramps. These symptoms can last for a day or two. Deep breath relaxation is useful for relaxing the body and reducing the pain of dysmenorrhea. This study aims to determine the effectiveness of deep breath relaxation on dysminorrhea pain in adolescents. Method The finding of journal articles was carried out electronically using several databases, they are: Google Garba Digital Reference (Garuda), and Google Cendekia (Google scholar) 5 articles were obtained to review. Results Of a study literature reveal that the effectiveness of deep breath relaxation purpose relieve primary dysmenorrhea pain in adolescent girls. Conclusion Is that the effectiveness of deep breath relaxation can reduce the intensity of primary dysmenorrhea pain in adolescents.

Keywords : Menstrual pain, Dysmenorrhea, Deep breath relaxation

\section{PENDAHULUAN}

Prevalensi dismenore di Indonesia sebesar $64,25 \%$ yang terdiri dari 54,89 dismenore primer dan $9,36 \%$ dismenore sekunder. Dismenore primer dialami oleh $60-75 \%$ remaja, dengan tiga perempat dari jumlah remaja tersebut mengalami nyeri ringan sampai berat. Apabila dismenore tidak segera ditangani maka dapat menimbulkan dampak bagi kegiatan atau aktivitas para wanita khususnya remaja. (Nur Indasari Z Dkk, 2020) 
Menstruasi merupakan suatu tanda mulai matangnya organ reproduksi pada remaja.Menstruasi dimulai antara usia 1215 tahun dan dapat menimbulkan berbagai gejala pada remaja, diantaranya konsentrasi buruk, sakit kepala terkadang disertai vertigo, perasaan cemas, gelisah dan nyeri perut (kram) atau biasa disebut dengan dismenore.(Aningsih Fidhi dkk., 2018)

Dismenore primer umumnya terjadi pada tahun-tahun pertama menstruasi atau menarche. Menstruasi pertama atau menarche pada anak gadis terjadi pada umur 10-16 tahun. Nyeri dimulai beberapa jam sebelum atau bersamaan dengan mulai menstruasi dan berlangsung selama 48 jam sampai 72 jam. Rasa nyeri yang hebat di sekitar bagian bawah yang menyebabkan kesulitan berjalan, tidak nafsu makan, mual, muntah dan bahkan sampai pingsan. (Nur Indasari Z Dkk., 2020)

Teknik relaksasi nafas dalam adalah bernafas dengan perlahan dan menggunakan diafragma, sehingga memungkinkan abdomen terangkat perlahan dan dada mengembang penuh. Cara melakukan teknik relaksasi nafas dalam, nafas lambat (menahan inspirasi secara maksimal) dan menghembuskan nafas secara perlahan, selain dapat menurunkan intensitas nyeri, teknik relaksasi nafas dalam juga dapat meningkatkan ventilasi paru dan meningkatkan oksigenasi darah. (Aningsih Fidhi Dkk, 2018).
Upaya yang telah dilakukan oleh pasien atau remaja yang mengalami dismenore yaitu pemberian obat analgesic untuk menurunkan nyeri. Namun, walaupun upaya ini telah dilakukan ternyata masih ada pasien yang mengeluhkan nyeri. Mungkin salah satu penyebabnya karena dalam penatalaksanaanya.(Suaib, 2019).

Berdasarkan paparan tersebut, maka penulis tertarik untuk melakukan telaah pustaka mengenai Efektivitas Relaksasi Nafas Dalam Terhadap Intensitas Nyeri Dismenore Primer Pada Remaja Putri.

\section{METODE PENELITIAN}

Studi ini merupakan suatu tinjauan literatur (literature review) yang mencoba menggali lebih banyak tentang efektivitas relaksasi nafas dalam untuk terhadap intensitas nyeri dismenore primer pada remaja putri. Metode untuk melakukan tinjauan literatur ini meliputi studi pencarian sistematis databased terkomputerisasi (Google Garba Rujukan Digital (Garuda), dan Google Cendekia (scholar Google)) Meliputi: bentuk jurnal penelitian berjumlah 5 artikel penelitian.

Penelitian (Suaib, 2019) yang berjudul "Pengaruh Relaksasi Nafas Dalam Terhadap Penurunan Intensitas Nyeri Haid Pada Remaja Putri Di MAN Insan Cendekia Halmahera Barat" Metode Penelitian yang digunakan Pra eksperimen dengan rancangan one group pre post-test design, yang diobservasi sebelum dilakukan intervensi, kemudian diobservasi lagi 
setelah diintervensi. Teknik pengambilan Sampel adalah Total Sampling. Instrumen yang digunakan yaitu kuesioner sedangkan teknik analisa data yaitu multivariat, dengan besar sampel sebanyak 27 orang. Saat responden mengalami nyeri haid primer kemudian diukur skala nyeri haidnya, kemudian setelah itu diukur kembali skala nyeri haidnya setelah 30 menit perlakuan. Hasil penelitian terdapat hubungan yang signifikan antara relaksasi nafas dalam terhadap penurunan intensitas nyeri haid pada siswi Remaja Putri di MAN Insan Cendekia Halmahera Barat yaitu dengan melihat hasil hitung statistik nilai $\mathrm{P}$ value $=0.0001$ yang berarti $\alpha<0.05$. Simpulan: teknik relaksasi Nafas dalam memberikan pengaruh signifikan terhadap intensitas nyeri haid pada Remaja Putri di MAN Insan Cendekia Halmahera Barat.

Penelitian (Fidhi Aningsih Dkk., 2020) yang berjudul “ Efektifitas Pemberian Teknik Relaksasi Nafas Dalam Terhadap Penurunan Nyeri Haid (Dismenore) Pada Remaja Putri Asrama Tahfizh Pondok Pesantren Ddi Ad Mangkoso". Metode penelitian ini quasi eksperimen dengan pendekatan one group pretest-posttest. Sampel yang diambil dalam penelitian ini adalah 45 responden dengan menggunakan Purposive Randon Sampling, dianalisis menggunakan Uji Wilxocon Rank Test, teknik relaksasi nafas dalam yang dilakukan selama 15 menit. Hasil penelitian didapatkan sesudah diberikan teknik relaksasi nafas dalam, dengan nilai $\mathrm{p}$-value $=0,000(\mathrm{p}<0,05)$ artinya H1 diterima yang berarti ada efek signifikan sesudah diberikan teknik relaksasi nafas dalam.

Penelitian (Indria Astuti Dkk., 2019) yang berjudul " pengaruh Teknik relaksasi nafas dalam terhadap penurunan intensitas nyeri disminore" Penelitian ini dilakukan dengan metode Pra Eksperimen dengan One Group Pratest-Posttest dengan sampel penelitian yang memenuhi kriteria inklusi sebanyak 23 orang. Pengolahan data menggunakan bivariat dengan uji Wilcoxon. teknik relaksasi nafas dalam bernapas lambat menggunakan diafragma, sehingga memungkinkan abdomen terangkat perlahan dan dada mengembang penuh. Hasil penelitian menunjukkan bahwa sebelum dilakukan teknik relaksasi nyeri ringan $39,19 \%$, sedang $47,8 \%$, terkontrol 13\%. Dan setelah dilakukan teknik relaksasi, intensitas tidak nyeri 52,29\% ringan $34,8 \%$ sedang $13,00 \%$. Dengan pvalue 0,00 bahwa ada pengaruh teknik relaksasi nafas dalam terhadap penurunan intensitas dismenore dengan $\mathrm{p}$-value $=$ 0,000 .

Beradasarkan penelitian (Silviani Elvira Yulita Dkk., 2019) yang berjudul Pengaruh "Teknik Relaksasi Nafas Terhadap Dismenore". Penelitian ini merupakan penelitian kuantitatif dengan metode pre Experiment meggunakan pendekatan one group pre-test and posttestt design yang terdiri dari kelompok yang diberikan intervensi yang sama. Populasi yaitu seluruh siswi kelas 2 dan 3 yang 
mengalami disminorea di SMA Negeri Purwodadi Kabupaten Musi Rawas Sumatera Selatan sebanyak 92 siswi. Pengambilan sampel menggunakan proporsional random sampling yaitu sebanyak 48 orang. Menggunakan kuesioner dalam bentuk checklist dan juga lembar observasi. Cara relaksasi yaitu posisi klien yang tepat, pikiran yang rileks dan lingkungan yang tenang. Hasil penelitian menunjukkan 33 siswi $(68,8 \%)$ mengalami nyeri dismenorea sedang sebelum dilakukan teknik relaksasi nafas, 19 siswi $(39,6 \%)$ tidak mengalami nyeri disminorea sesudah dilakukan teknik relaksasi nafas, dan ada pengaruh yang signifikan antara teknik relaksasi nafas dengan disminorea di SMA Negeri Purwodadi Kabupaten Musi Rawas Sumatera

Berdasarkan penelitian (Brahim Dkk., 2020) yang berjudul "Efektivitas Teknik Relaksasi Nafas Dalam Terhadap Penurunan Nyeri Haid (Dismenore)" penelitian ini menggunakan Pre Exsperiment dengan desain one-group pre test-post test berjumlah 60 orang, teknik sampel menggunakan metode purposive. Pengumpulan data menggunakan kuesioner dengan cara angket. Data di olah secara manual dengan langkah editing, coding, entry, tabulating dan cleaning dan analisis secara univariat menggunakan statistik deskriptif dan analisis bivariat menggunakan uji t-test dependen dengan tingkat kemaknaan $95 \% \quad(\alpha=0,05)$. Hasil penelitian didapatkan rata-rata skala nyeri sebelum diberikan perlakuan adalah 6,27 dan sesudah diberikan perlakuan adalah 2,80. Berarti nafas dalam efektif terhadap penurunan nyeri haid berdasarkan hasil uji $\mathrm{t}$-test didapatkan nilai $\mathrm{p}=0,000(\mathrm{p}=\leq 0,05)$. Hasil dapat disimpulkan ada efektifitas teknik relaksasi nafas dalam terhadap penurunan nyeri haid (dismenore).

\section{HASIL DAN PEMBAHASAN}

Berdasarkan telaah pustaka dengan mengkaji 5 artikel penelitian didapatkan persamaan dan perbedaan dari mulai tekhnik sample, metode penelitian, instrumen penelitian, dan prosedur yang dilakukan.

Pada tekhnik pengambilan sample didapatkan perbedaan yaitu ada yang menggunakan Total Sampling, proporsional random sampling, motode purposive dan sampel penelitian yang memenuhi kriteria.

Pada metode penelitian ini juga di dapatkan perbedaan ada yang menggunakan Praeksperimen dengan rancangan one group pre-post test deisign, quasi eksperimen dengan pendekatan one group pre test-post test, pre Experiment meggunakan pendekatan one group pre-test and post test design, dan Pre Exsperiment dengan desain one-group pre test-post test.

Dalam prosedur penelitian juga di dapatkan perbedaan dalam Teknik relaksasi nafas dalam pengukuran skala nyeri haidnya setelah 30 menit perlakuan, teknik 
relaksasi nafas dalam yang dilakukan selama 15 menit, teknik relaksasi nafas dalam bernapas lambat dan bagaimana cara menghembuskan nafas secara dalam, cara relaksasi yaitu posisi klien yang tepat, pikiran yang istirahat dan lingkungan yang tenang

Dalam instrumen penelitian juga di dapatkan perbedaan yaitu ada yang menggunakan wawancara dan ada yang menggunakan lembar observasi. Adapun didapatkan persamaan nya yaitu menggunakan teknik relaksasi nafas dalam.

Hasil studi literatur mengungkapkan bahwa efektivitas relaksasi nafas dalam sebagai upaya preventif yang dapat menurunkan skala nyeri disminore dengan rata-rata hasil penelitian $\mathrm{P}$-value $=0,000$ yang berarti $\alpha<0.05$.

Teknik relaksasi nafas dalam dipercaya dapat menurunkan intensitas nyeri melalui mekanisme yaitu :

1. Dengan merelaksasikan otot-otot skelet yang mengalami spasme yang disebabkan oleh peningkatan prostaglandin sehingga terjadi vasodilatasi pembuluh darah dan akan meningkatkan aliran darah ke daerah yang mengalami spasme dan iskemic.

2. Teknik relaksasi nafas dalam dipercayai mampu merangsang tubuh untuk melepaskan opoiod endogen yaitu endorphin dan enkefalin

3. Teknik relaksasi nafas dalam yang dilakukan selama 15 - 30 menit dapat merelaksasikan tubuh secara umun, memberikan rasa nyaman sehingga intensitas nyeri yang dirasakan berangsur menghilang

4. Mudah dilakukan dan tidak memerlukan alat Relaksasi melibatkan system otot dan respirasi dan tidak membutuhkan alat lain sehingga mudah dilakukan kapan saja atau sewaktu-waktu.

\section{KESIMPULAN DAN SARAN}

Setelah dilakukan telaah pustaka dari beberapa artikel penelitian dapat disimpulkan bahwa teknik relaksasi nafas dalam efektif untuk menurunkan intensitas nyeri disminore primer pada remaja putri.

\section{SARAN}

1. Bagi Institusi Kesehatan

Sebagai tenaga kesehatan khusunya bidan, diharapkan memberikan informasi mengenai Kesehatan reproduksi, khusunya seputar nyeri saat disminore primer dan memberikan cara yang efektif untuk menanganinya, salah satunya dengan teknik relaksasi nafas dalam.

2. Bagi Institusi Pendidikan

Dapat dijadikan sebagai salah satu metode yang bisa dipelajari dan digunakan sebagai pembelajaran kepada mahasiswa sebagai salah satu cara untuk mengurangi nyeri dismenore primer pada remaja putri dengan tehnik relaksasi nafas dalam. 


\section{DAFTAR PUSTAKA}

Brahim, Prawata, A. H. M., \& Yetika, W. (2020). Efektivitas Teknik Relaksasi Nafas Dalam Terhadap Penurunan Nyeri Haid (Dismenore) Pada Siswi. Jurnal Ilmu Kebidanan (Journal Of Midwifery Sciences)Urnal Abdimas Saintika, 2 No.1.

Fidhi Aningsih, Eka Sudiwati, N. D. (2018). Pengaruh Pemberian Teknik Relaksasi Nafas Dalam Terhadap Penurunan Intensitas Nyeri Haid (Dismenore) Pada Mahasiswi Di Asrama Sanggau Landungsari Malang. Nursing News, Volume 3,.

Indria Astuti*, Rd Noucie Septriliana, M. S. (2019). The Influence Of Breathing Relaxation Technique In The Decrease Of Dismenore Intensity. Third International Seminar On Global Health, Volume $3 \mathrm{~N}$.

Nur Indasari Z*, Haniarti, H. K. H. (2020). Efektifitas Pemberian Teknik Relaksasi Nafas Dalam Terhadap Penurunan Nyeri Haid (Dismenore)
Pada Remaja Putri Asrama Tahfizh Pondok Pesantren Ddi Ad Mangkoso. Jurnal Ilmiah Manusia Dan Kesehatan, Vol. 3, No.2.http://jurnal.umpar.ac.id/index .php/makes

Trisnabari, H. M., \& Wahyuni. (2018). Manfaat Deep Breathing Exercise Terhadap Nyeri Haid Primer Pada Mahasiswi S1 Fisioterapi Universitas Muhammadiyah Surakarta. The 7th University Research Colloqium, 755-761.

Suaib, N. (2019). Pengaruh Relaksasi Nafas Dalam Terhadap Penurunan Intensitas Nyeri Haid Pada Remaja Putri Di Man Insan Cendekia Halmahera Barat. Jurnal Medikes (Media Informasi Kesehatan), 6(2), 193-202.

https://doi.org/10.36743/medikes.v $6 i 2.183$

Yulita Elvira Silviani, Buyung Karaman, P. S. (2019). Pengaruh Teknik Relaksasi Nafas Terhadap Dismenorea. Hasanuddin Journal of Midwifery, Volume 1(1). 